\title{
A Convenient and Versatile Synthesis of 2' (and 3')-Amino (and azido)- 2' (and 3')-deoxyadenosine as Diverse Synthetic Precursors of Cyclic Adenosine Diphosphate Ribose (cADPR)
}

\author{
Beom-Tae Kim, Seung-Ki Kim, Seung-Jae Lee, and Ki-Jun Hwang* \\ Department of Chemistrv, and Research Center of Bioactive Materials, College of Natural Science. \\ Chonbuk Nationd Liviversity. Dukjindong 66t-14, Choniu 561-756, Korea \\ Received November 14, 2003
}

\begin{abstract}
As diverse synthet ic precursors of cyclic adenosine diphosphate ribose (cADPR), several adenosine derivatives in which azido or amino group is introduced at 2'- or 3'-position of the sugar moicly of adenosine were prepared from readily available adenosine via conventional protocols. These synthetic sequence employs very efficient reactions conditions that proceed at or below ambient temperature with actual yiclds of $>80 \%$ for each individual step.
\end{abstract}

Key Words : Cyclic adenosine diphosphate ribose (cADPR), 2' (and 3')-Amino (and azido)- $2^{\prime}$ (and 3')-deoxyadenosine

\section{Introduction}

Cyclic adenosine diphosphate ribose (cADPR, 1) is a naturally occurring cyclic nucleotide and a general mediator involved in $\mathrm{Ca}^{2-}$ signaling in a variety of mammalian and invertebrate tissues. ${ }^{1}$ Also, recent studies reveal the involvement of cADPR in glucose-dependant insulin secretion in pancreatic cells, proliferation of human T-lymphocytes, and arrhythmogenic oscillations of intracelluar $\mathrm{Ca}^{2+}$ in heart cells etc. ${ }^{2-1}$ Those findings suggest the therapeutic potential of CADPR itself or its derivatives against diabetes, immune and cardiovascular diseases. Therefore, considerable progress has been made in the synthesis of CADPR analogues and the evaluation of their biological effects. In general, the synthetic strategy to prepare CADPR analogues includes intracycli- zation of $\mathrm{NAD}^{+}$analogues (Figure 1), which can be prepared from the appropriately designed nucleosides/nucleotides. ${ }^{5}$ However, the reported precedents have limitation for the facile preparation of various nucleosides/nucleotides from readily available starting materials. ${ }^{1.5}$ To our knowledge. analogues of cADPR have been prepared from commercially available nucleosides/nucleotides as starting materials in most cases. So, there are still urgent needs for the development of new and diverse nucleosides with more convenient chemical routes.

Most of structural modifications occurred on the adenosine moiety of cADPR, namely, purine and sugar, In particular, a few previous researches show that the structural modification in sugar, especially at $2^{\prime}$ and/or $3^{\prime}$-position gives rise to remarkable changes in their activities, namely, considerable

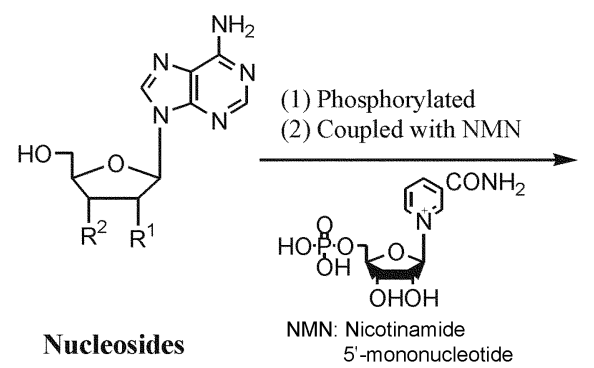

Nucleosides

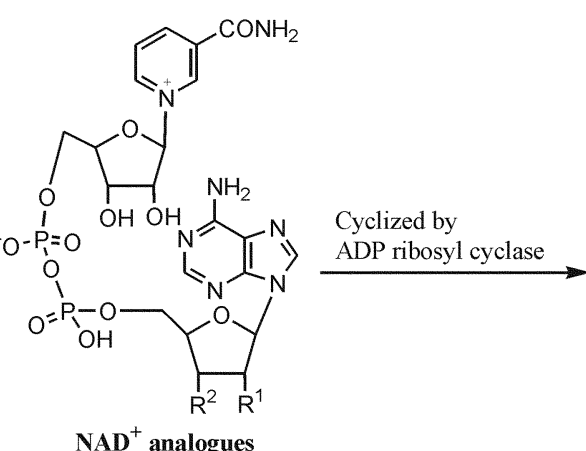

$$
\begin{aligned}
& 1 \mathrm{R}^{1}=\mathrm{R}^{2}=\mathrm{OH} \\
& 2 \mathrm{R}^{1}=-\mathrm{OPO}_{3}^{2-}, \mathrm{R}^{2}=\mathrm{OH} \\
& 3 \mathrm{R}^{1}=\mathrm{H}^{2}, \mathrm{R}^{2}=-\mathrm{OPO}_{3}^{2-} \\
& 4 \mathrm{R}^{1}, \mathrm{R}^{2}=-\mathrm{O}-\mathrm{OP}^{\mathrm{M}} \cdot \mathrm{O}- \\
& \mathrm{O}^{-}
\end{aligned}
$$

\section{cADPR analogues}

Figure 1

\footnotetext{
"Conesponding Author: Tel: +82-63-270-3577, Гax: +82-63-270-4322, c-mail: kijun almoak.chonbuk.ac.kr
} 


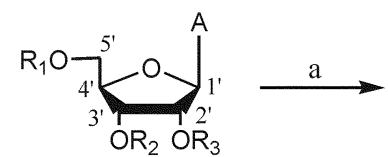

$8 \quad \mathrm{R}_{1}=\mathrm{R}_{2}=\mathrm{R}_{3}=\mathrm{H}$

9a $\mathrm{R}_{1}=\mathrm{R}_{3}=$ TBDMS, $\mathrm{R}_{2}=\mathrm{H}$

9b $R_{1}=R_{2}=$ TBDMS, $R_{3}=H$

9c $\mathrm{R}_{1}=\mathrm{R}_{2}=\mathrm{R}_{3}=$ TBDMS

$$
A=\underbrace{2}_{3}
$$

$\mathrm{Tf}=$ trifluoromethanesulfonyl $\mathrm{Ms}=$ methanesulfonyl

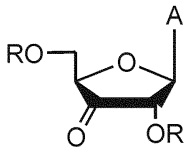

$10 \mathrm{R}=\mathrm{TBDMS}$
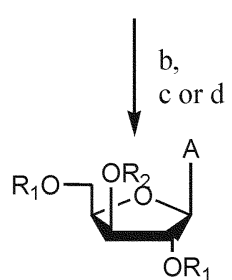

$12 \mathrm{R}_{1}=$ TBDMS, $\mathrm{R}_{2}=\mathrm{H}$

$13 \mathrm{R}_{1}=$ TBDMS, $\mathrm{R}_{2}=\mathrm{Ms}$

$14 \mathrm{R}_{1}=$ TBDMS, $\mathrm{R}_{2}=\mathrm{Tf}$

$$
\downarrow \text { eor } \mathrm{f}
$$

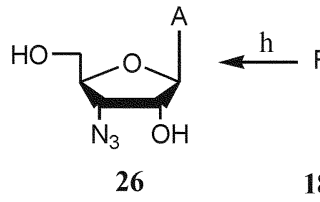

$19 \mathrm{R}_{1}=\mathrm{H}_{1} \mathrm{R}_{2}=\mathrm{TBDMS}$
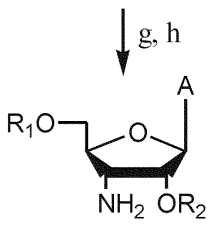

$22 \mathrm{R}_{1}=\mathrm{R}_{2}=$ TBDMS

$23 \mathrm{R}_{1}=\mathrm{R}_{2}=\mathrm{H}$

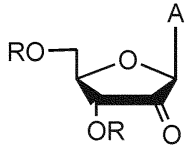

$11 \mathrm{R}=$ TBDMS
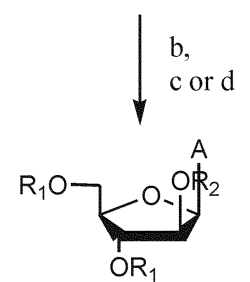

$15 \mathrm{R}_{1}=$ TBDMS, $\mathrm{R}_{2}=\mathrm{H}$

$16 \mathrm{R}_{1}=$ TBDMS, $\mathrm{R}_{2}=\mathrm{Ms}$

$17 \mathrm{R}_{1}=$ TBDMS, $\mathrm{R}_{2}=\mathrm{Tf}$

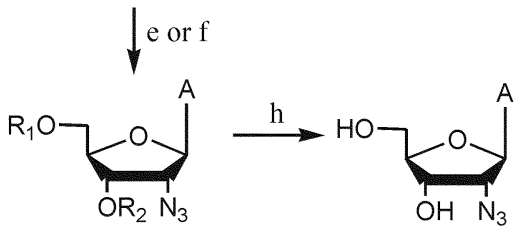

$20 \mathrm{R}_{1}=\mathrm{R}_{2}=$ TBDMS

27

$21 \mathrm{R}_{1}=\mathrm{H}, \mathrm{R}_{2}=$ TBDMS

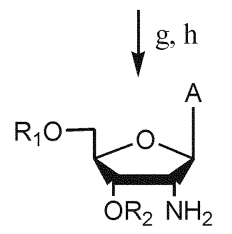

$24 \mathrm{R}_{1}=\mathrm{R}_{2}=$ TBDMS

$25 \mathrm{R}_{1}=\mathrm{R}_{2}=\mathrm{H}$

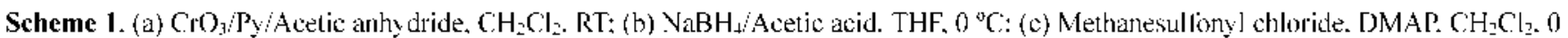

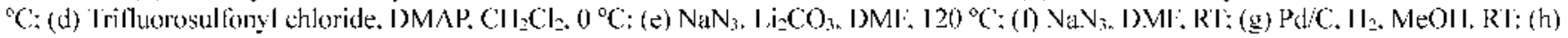
$\mathrm{NH}$.1. MeOHI. $60^{\circ} \mathrm{C}$.

change in agonistic activity $(\mathbf{2}, \mathbf{5}, \mathbf{6})$, showing no activities $(3,4)$, and even reversed activity (7). (Figure 1) ${ }^{1: i}$ As mentioned above, however, as the lack of sufficient analogues obtained to date, the relationship between the functionality at $2^{\prime}$ and or $3^{\prime}$-position in sugar moiety and their $\mathrm{Ca}^{2-}$ modulating capacities has not been fully understood.

In this point of view, as a part of our synthetic effort to synthesize nucleosides having diverse functionality at $2^{\prime}$ or 3 -position of sugar moiety, we designed aminosugar (and azidosugar) nucleosides (23, 25, 26 and 27, Scheme 1) in which 2'- or 3'-hydroxy group in ribose moiety is replaced with primary amine group and azido group. Since amino group is similar to hydroxy group in size and in hydrogenbonding character, and azido group shows interesting biological features when it is introduced to sugar moiety as shown in the example of $\mathrm{AZT}{ }^{\circ}$ it is considered to be interesting to us to investigate the activity variation of CADI'R with amine and azido functionality at sugar moiety. Although there are precedences for the preparation of $2^{\prime}$ (and $3^{\prime}$ )-aminoadenosine analogues, ${ }^{7.9}$ their synthetic routes are fairly laborious and furthermore each compound should be prepared in separate ways. So, our synthetic strategy was designed in a way that these target compounds (2' and $3^{\prime}$ - substituted products) can be prepared very efficiently using the same reaction steps starting from the disilylated adenosine analogs (9a and $9 \mathbf{b}$ ) obtained simultaneously in first step (Scheme 1). We now describe the synthesis of $2^{\prime}$ (and $3^{\prime}$ )deoxy-2' (and $3^{\prime}$ )-azido-adenosine $\left(27,26\right.$ ) and $2^{\prime}$ (and $3^{\prime}$ )deoxy $-2^{\prime}$ (and $3^{\prime}$ )-amino-adenosine $(25,23$ ) starting from adenosine in very efficient manner by employing conventional protocols with actual yields of $>80 \%$ for each individual reaction steps (Scheme 1).

\section{Results and Discussion}

Treatment of adenosine with tert-butyldimethylsilyl ('BBDMS) chloride gave silyl-protected compounds, 2',5'bis- $O$-(tert-butyldimethylsilyl)adenosine (9a) and $3^{\prime} 5^{\prime}$-bis$O$-(tert-butyldimethylsilyl)adenosine (9b) in $47 \%$ and $30 \%$ isolated yield, respectively, together with small amount of $2 ', 3,5^{\prime}$-tris-()-(tert-butyldimethylsilyl)adenosine $(\mathbf{9 c}){ }^{10}$ Oxidation (chromium trioxide/pyridine/acetic anhydride) of these 2',5'- and 3',5'-()-'TBDMS-protected adenosine gave the corresponding 3'-keto- and 2'-ketoadenosines (10 and 11 ) in about $90 \%$ yield. " These individual ketonucleotides are known to be useful intermediates for the synthesis of a 
variety of sugar-modified nucleosides and have been enployed to change configuration at $\mathrm{C}^{\prime}$ and $\mathrm{C}^{\prime}$ vic oxidation-reduction sequence. ${ }^{12}$ Although the oxidation of the protected alcohols 9a and 9b to their ketoadenosine 10 and 11 , occurred successfully eventually, the chemical properties of compound 11 deserve some mention. Thus, treatment of $9 \mathrm{a}$ with the oxidizing agents gave ketoadenosine 10 very nicely with no incidence, which is easily identified by its clear TLC pattern. ${ }^{11}$ In the case of 2 -ketoadenosine (11). however. there were some problems in separation due to the broad TLC pattern (tailing), which caused difficulty in purification. The ${ }^{1} \mathrm{H}-\mathrm{NMR}$ analysis of the crude compound 11 exhibited the line broadening and doubling of purine peaks, which is consistent with the results reported by F. Hansske $e t a^{11 \mathrm{~b}}$ This is likely caused by the formation of $\mathrm{Cr}$ complex and its existence as equilibrium mixture of ketone and ketone hydrate ${ }^{1 j} \mathrm{In}$ fact, isolated 2'-ketoadenosine 11 showed very low solubility in ethyl acetate and methylene chloride and the yield was not realized as reported. However, this low yield problem was overcome by using more polar elution solvent (EtOAc-MeOH $=9: 1$. v/v) during chromatography work, and the identity of 2'-ketoadenosine undefined on TLC was confirmed through consecutive reduction which gave arabinofuranosyl derivative (15). In other words. 2'ketoadenosine 11 can be utilized directly for the next step without purification. although it seems to be inpure by TLC after the oxidation.

$2^{\prime}$ (and $3^{\prime}$ )-Ketonucleosides 11 and $\mathbf{1 0}$ were converted to the corresponding arabino (15) and xylofuranosyl nucleoside (12) with high stereoselectivity according to the modified method of M. J. Robins. ${ }^{119}$ In original method. excess sodium triacetoxyborolydride was used rather than $\mathrm{NaBH}_{4}$ as a reducing agent. However. it's not convenient to prepare sodium triacetoxyborohydride and a long reaction time ( 48 hours) and strict temperature $\left(13^{\circ} \mathrm{C}\right)$ control was required for their case. In contrast. in our modified method. THF was used as a reaction solvent in the preparation of sodium triacetoxyborolydride (generated in situ by adding excess $\mathrm{AcOH}$ to the suspension of $\mathrm{NaBH}_{4}$ in THF at $0{ }^{\circ} \mathrm{C}$ ) and reaction was performed at $0^{\circ} \mathrm{C}$. To our surprise, the reaction time became much more shorter (less than 4 hours) with the consistent high yields (>90\%).

Next we moved on to introduce azide group at 2' position of arabinofuranosyl nucleoside 15 and $3^{\prime}$ position of xylofuranosyl nucleoside 12. The first step to mesylate compounds 15 and 12 occurred with no incidence to produce compound 16 and 13 in $93 \%$ and $92 \%$ yield, respectively. Treatment of 16 and 13 with $\mathrm{NaN}_{3}$ or $\mathrm{LiN}_{3}$ according to known procedure. ${ }^{6.13}$ however, produced the desired azido compound 20 and 18 in very poor yields $(10-40 \%)$ along with $5^{\prime}$-deprotectd azido compounds 21 and 19 (6-15\% yield). These problems, however, was easily overcome by utilizing triflate 17 and 14 . Thus. the azido group was quantitatively introduced into the 2 ' (and 3')-position of corresponding triflates (17 and 14) using $\mathrm{NaN}_{3}$ at room temperature ${ }^{14}$ to produce 20 and $\mathbf{1 8}$.

With these silyl protected azide compounds $\mathbf{2 0}$ and $\mathbf{1 8}$ in hand. several chemical transformations to produce our key intermediates were carried out. First, simple treatment of $\mathbf{2 0}$ and 18 with $\mathrm{NH}_{4} \mathrm{~F} / \mathrm{MeOH}$ at $60^{\circ} \mathrm{C}$ gave silyl groupdeprotected azido compounds 27 and 26 quantitatively. ${ }^{15}$ Second. the azido group of compounds 20 and 18 was reduced with $\mathrm{H}_{2}$ in $\mathrm{MeOH}$ in the presence of $\mathrm{Pd} / \mathrm{C}$ without loss of the TBDMS protecting groups to produce silyl group-protected amino compounds $\mathbf{2 4}$ and $\mathbf{2 2}$ in $\mathbf{9 0 \%}$ and $92 \%$ yield. respectively. Third. the silyl group of amino compounds 24 and 22 can be deprotected under the same condition to give silyl group-deprotected amino compounds 25 and 23 in $87 \%$ and $85 \%$ purified yield. respectively. The desilylation step is apparently occurred in two-steps on the analysis of TLC, and so the selective desilylation of our particular compounds is possible upon needed.

In summary, these convenient and efficient sequence for the preparation of adenosine analogues (23. 25, 26, 27), which are crucial intermediate for the structural modification of CADPR, were described. In particular. the improvement in the reduction procedure using THF as a co-solvent for the preparation of xylo- and arbinofuranosyl nucleoside (12 and 15 ) is noticeable in terms of efficiency and convenience. More importantly, compared to other precedent procedures, our synthetic strategy is convenient and versatile as well, from the points of view that several target compounds can be prepared using same starting material via continuous and consecutive processes. With these compounds in hand, the synthetic work for the preparation of CADPR analogs and further modification at adenine moiety is now in progress.

\section{Experimental Section}

Melting points were recorded on electrothermal melting point apparatus and are uncorrected. Mass spectra were recorded on a JEOL JMS-DX 303 mass spectrometer (3 $\mathrm{KV}$ ). ${ }^{1} \mathrm{H}-\mathrm{NMR}$ and ${ }^{13} \mathrm{C}$-NMR data were obtained from Jeol $400 \mathrm{MHz}$ spectrometer and chemical shifts $(\delta)$ were reported in ppm in relation to tetramethylsilane $(\delta 0.00)$ and $\mathrm{CDCl}_{3}(\delta$ 77.0) for ${ }^{1} \mathrm{H}$ and ${ }^{13} \mathrm{C}$. NMR, respectively: J values are in hertz $(\mathrm{Hz})$. Thin layer chromatography was performed on precoated silica gel $60 \mathrm{~F}-254$ (layer thickness $0.2 \mathrm{~mm}$. Merck). The Flash Column Chromatography was performed on Merck silica gel type 60 (230-400 mesh). Unless specified otherwise the solvent system for all cluromatography was $\mathrm{EtOAc} / \mathrm{Hexane}(7: 3, \mathrm{v} / \mathrm{v})$. The organic solvents and chemicals were obtained from Aldrich. Co. and purified by the appropriate methods before use.

Silylation of Adenosine. TBDMSCl (8.46 g. $56.13 \mathrm{mmol}$ ) was added to a suspension of $8(5.0 \mathrm{~g} .18 .7 \mathrm{mmol})$ in pyridine $(35 \mathrm{~mL})$ and stirred at ambient temperature for $48 \mathrm{~h}$ under $\mathrm{Ar}$ atmosphere. The solvent was evaporated and the residue partitioned (ice-cold $5 \% \mathrm{HCl} / \mathrm{H}_{2} \mathrm{O} / / \mathrm{CH}_{2} \mathrm{Cl}_{2}$ ). The organic phase was washed (saturated $\mathrm{NaHCO}_{3} / \mathrm{H}_{2} \mathrm{O}$ and brine), dried $\left(\mathrm{MgSO}_{4}\right)$, and evaporated. The white solid was suspended in EtOAc and applied to a column and separated by Yamazen MPLC system (flow rate: $20 \mathrm{~mL} / \mathrm{min}$. detected at $254 \mathrm{~nm}$ ) to give $2^{\prime} .5^{\prime}$-bis-O-(tert-buty ldimethylsilyl)- 
adenosine (9a. 47\%). 3'.5'-bis-O-(tert-butyldinethylsilyl)adenosine (9b, 30\%), 2'.3'.5'-tris-O-(tert-butyldimethylsilyl)adenosine $(9 \mathrm{c}, 4 \%)$ as white powders with expected spectral properties. ${ }^{j i}$

9-[2',5'-Bis-O-(tert-butyldimethylsilyl)-1- $\beta$-D-erythropentofuran-3'-ulosyl]adenine (10). Procedure A. pyridine $(2.5 \mathrm{~mL}, 30.7 \mathrm{nmol})$ and $\mathrm{Ac}_{2} \mathrm{O}(1.45 \mathrm{~mL}, 15.4$ numol $)$ were added consecutively to an ice-cold suspension of $\mathrm{CrO}_{3}(1.54$ g. $15.4 \mathrm{mmol})$ in $\mathrm{CH}_{2} \mathrm{Cl}_{2}(50 \mathrm{~mL})$ and stirred until homogeneous (10-15 mill) at ambient temperature under $\mathrm{Ar}$ atmosphere. A solution of $9 \mathrm{a}(3.81 \mathrm{~g} .7 .67 \mathrm{mmol})$ in $\mathrm{CH}_{2} \mathrm{Cl}_{2}$ $(10 \mathrm{~mL}$ ) was added. stirring was continued for $2 \mathrm{~h}$. The reaction mixture was poured into cold EtOAc ( 1 L) and filtered (glass microfiber filter, GF/A). The filtrate was concentrated and purification (short column chromatography. EtOAc) gave $10(3.37 \mathrm{~g}, 89 \%)$ as a colorless powder with reported properties. ${ }^{11}$

9-[3',5'-Bis- $O$-(tert-buty]dimethylsilyl)-1- $\beta$-D-erythropentofuran-3'-ulosyl]adenine (11). Oxidation of $9 \mathrm{~b}$ (1.50 g. 3.02 nmol) by procedure $\mathbf{A}\left[\mathrm{CrO}_{3}(0.61 \mathrm{~g} .6 .04 \mathrm{mmol}) /\right.$ pyridine $(0.98 \mathrm{~mL}, 12.1 \mathrm{mmol}) / \mathrm{Ac}_{2} \mathrm{O}(0.57 \mathrm{~mL}, 6.04 \mathrm{mmol}) /$ $\left.\mathrm{CH}_{2} \mathrm{Cl}_{2}(25 \mathrm{~mL})\right]$ gave $11(1.32 \mathrm{~g} .89 \%)$ as a pale yellow powder with reported properties. ${ }^{11}$ The purification was performed on the short columu chromatography eluted with EtOAc-MeOH $(9 ; 1)$.

9-[2',5'-Bis- $\boldsymbol{O}$-(tert-butyldimethỵlsily])-1- $\boldsymbol{\beta}$-D-xylofuranosyl]adenine (12). Procedure B. Ketone 10 (1.0 g. 2.03 mmol) was added to a mixture of $\mathrm{NaBH}(\mathrm{OAc})_{3} / \mathrm{THF} / \mathrm{AcOH}$ [generated in situ by addion of $\mathrm{AcOH}(7 \mathrm{~mL})$ to a suspension of $\mathrm{NaBH}_{4}(0.92 \mathrm{~g}, 24.3 \mathrm{mmol})$ in THF $(50 \mathrm{~mL})$ and then stirred for $1.5 \mathrm{~h}$ at $0^{\circ} \mathrm{C}$ under $\mathrm{Ar}$ atmosphere]. The reaction was stirred for $t h$ at $0^{\circ} \mathrm{C}$, and volatiles were evaporated. The residue was partitioned (EtOAc/sat. aqueous $\mathrm{NaHCO}_{3}$ ), and the aqueous layer was extracted with EtOAc. The combined organic phase was washed $\left(\mathrm{H}_{2} \mathrm{O}\right.$, brine $)$. dried over $\mathrm{MgSO}_{4}$, filtered. and evaporated. The oily residue was applied to flash columm chromatography to give $12(0.90 \mathrm{~g}$. $90 \%$ ) as a colorless powder with reported properties. ${ }^{11}$

9-[3',5'-Bis- $O$-(tert-butyldimethylsilyl)-1- $\beta$-D-arabinofuranosyl]adenine (15). Treatment of ketone $11(1.30 \mathrm{~g}$. 2.63 nimol) by procedure $\mathbf{B}\left[\mathrm{NaBH}_{4}(1.20 \mathrm{~g} .31 .6 \mathrm{mmnol})\right.$ in THF $(60 \mathrm{~mL}) / \mathrm{AcOH}(9 \mathrm{~mL})]$ gave $15(1.02 \mathrm{~g} .79 \%)$ as a colorless powder with reported properties. ${ }^{\text {lla }}$

9-[3'-O-(Trifluormethanesulfony])-2',5'-Bis- $O$-(tert-butyldimethylsilyl)-1- $\boldsymbol{\beta}$-D-xylofuranosyl]adenine (14). Procedure $C$. To a solution of $12(2.26 \mathrm{~g} .4 .56 \mathrm{~mm}$ mol $)$ and DMAP (1.68 g. $13.68 \mathrm{mmol}$ ) in $\mathrm{CH}_{2} \mathrm{Cl}_{2}(15 \mathrm{~mL})$ was added fresh trifluoromethanesulfonyl clloride $(0.53 \mathrm{~mL} .5 .01 \mathrm{mmol})$ at 0 ${ }^{\circ} \mathrm{C}$ under $\mathrm{Ar}$ atmosphere. The reaction was stirred for $15 \mathrm{~min}$ at this temperature and then checked by TLC. A second portion of trifluoromethanesulfonyl chloride $(0.1 \mathrm{~mL} .0 .94$ mmol) was added and stirring was continued for 15 min at 0 ${ }^{\circ} \mathrm{C}$. The reaction was partitioned (ice-cold $1 \%$ aqueous $\mathrm{AcOH} / \mathrm{CH}_{2} \mathrm{Cl}_{2}$ ), and the aqueous layer was extracted with $\mathrm{CH}_{3} \mathrm{Cl}_{3}$. The combined organic phase was washed (ice-cold saturated aqueous $\mathrm{NaHCO}_{3}$, ice-cold brine). dried over $\mathrm{MgSO}_{4}$, filtered, and evaporated. Flash chromatography gave colorless powder of $13\left(2.23 \mathrm{~g} .78 \%\right.$ ): mp: $48-52{ }^{\circ} \mathrm{C}$ (softening): ${ }^{1} \mathrm{H}$ NMR, $\mathrm{CDCl}_{3} \delta 8.20(\mathrm{~s}, 1 \mathrm{H} . \mathrm{H} 8), 7.9 \mathrm{l}(\mathrm{s}, \mathrm{lH} . \mathrm{H} 2) .6 .43$ (br, $2 \mathrm{H} . \mathrm{NH}_{2}$ ). 5.95 (d. lH. $J=2.0 \mathrm{~Hz}, \mathrm{Hl}$ ). 5.01 (m, lH, H2'), 4.82 (m, IH. H3'), 4.42 (m, lH, H4'). 3.99 (m. 2H. H5'a, H5'b). 0.79 (s, 9H, t-butyl). $0.75(\mathrm{~s}, 9 \mathrm{H}, t$-butyl) 0.00 (s. $6 \mathrm{H}$. methyl $\times 2$ ), -0.02 (s. $3 \mathrm{H}$. methyl). -0.10 (s. $3 \mathrm{H}$. methyl): ${ }^{12} \mathrm{C}$-NMR $\delta 155.63,152.93,149.48 .137 .79 .119 .60 .89 .74$ $88.38,80.46 .79 .06,60.07,25.46 .25 .33 .18 .24,17.65,-5.16$, $-5.34 .-5.59 .-5.60$.

9-[2'- $O$-(Trifluormethanesulfony])-3',5'-bis- $O$-(tert-butyldimethylsilyl)-1- $\beta$-D-arabinofuranosyl]adenine (17). Treatment of 15 (1.39 g, $2.80 \mathrm{mmol}$ ) by procedure $\mathbf{C}$ [DMAP ( $1.03 \mathrm{~g} .8 .41 \mathrm{mmol})$ in $\mathrm{CH}_{2} \mathrm{Cl}_{2}(10 \mathrm{~mL}) /$ trifluoromethanesulfonyl chloride $(0.33 \mathrm{~mL}, 3.08 \mathrm{mmol}$ and 0.07 $\mathrm{mL}, 0.66 \mathrm{mmol})]$ gave $16(1.45 \mathrm{~g}, 82 \%)$ as a colorless powder: $\mathrm{mp}$ : $116-118{ }^{\circ} \mathrm{C}$ : ${ }^{1} \mathrm{H}-\mathrm{NMR}, \mathrm{CDCl}_{3} \delta 8.25$ (s. $1 \mathrm{H}$, H8). 7.89 (s. IH, H2). 6.48 (d, IH. $J=4.0 \mathrm{~Hz} . \mathrm{Hl}$ ') 5.59 (br, 2H. $\mathrm{NH}_{2}$ ). 5.10 (m. 1H, H2) 4.67 (m. lH, H3), 3.93 (m, IH. H4'). 3.80 (dd. $2 \mathrm{H} . J=4.4,10.8 \mathrm{~Hz}$. H5'a), 3.72 (dd. $1 \mathrm{H}$, $J=6.4 .10 .8 \mathrm{~Hz}$. H5'b). 0.83 (s. $9 \mathrm{H}$. $t$-butyl), 0.82 (s. $9 \mathrm{H}$, t-butyl) $0.07(\mathrm{~s}, 6 \mathrm{H}$. methyl $\times 2) .0 .00(\mathrm{~s}, 6 \mathrm{H}$. methyl $\times 2)$.

9-[3'- $O$-(Methanesulfonyl)-2',5'-bis- $O$-(tert-butyldimethy]silyl)-1- $\boldsymbol{\beta}$-D-xylofuranosyl]adenine (13). Procedure D. To a solution of $12(1.50 \mathrm{~g} .3 .02 \mathrm{mmol})$ and DMAP (1.11 g, 9.08 numol) in $\mathrm{CH}_{2} \mathrm{Cl}_{2}$ ( $10 \mathrm{~mL}$ ) was added fresh methanesulfonyl chloride $(0.28 \mathrm{~mL} .3 .63 \mathrm{mmol})$ at $0^{\circ} \mathrm{C}$ under $\mathrm{Ar}$ atmosphere. The reaction was stirred for $3 \mathrm{~h}$ at this temperature and then checked by TLC. A second portion of methanesulfonyl chloride (0.1 mL. 1.29 mmol) was added and stirring was continued for $1 \mathrm{~h}$ at $0^{\circ} \mathrm{C}$. The reaction was partitioned between ice-cold $1 \%$ aqueous $\mathrm{AcOH}$ and $\mathrm{CH}_{2} \mathrm{Cl}_{2}$. and the aqueous layer was extracted once more with $\mathrm{CH}_{2} \mathrm{Cl}_{2}$. The combined organic phase was washed (ice-cold sat aqueous $\mathrm{NaHCO}_{3}$, ice-cold brine), dried over $\mathrm{MgSO}_{4}$, filtered, and evaporated to give 13 (1.59 g. 92\%) as a colorless solid: mp: $57.58^{\circ} \mathrm{C}$ : ${ }^{1} \mathrm{H}-\mathrm{NMR}, \mathrm{CDCl}_{3} \delta 8.27$ (s, 1H. H8), 8.05 (s, IH. H2), 6.20 (br, $2 \mathrm{H}, \mathrm{NH}_{2}$ ), 6.04 (d, IH. J $\left.=2.0 \mathrm{~Hz}, \mathrm{Hl}^{\prime}\right) .4 .88\left(\mathrm{~m}, \mathrm{lH}, \mathrm{H} 2^{\prime}\right), 4.76$ (m. IH. H3'). 4.45 (dd, $1 \mathrm{H}, J=4.4 .10 .8 \mathrm{~Hz} . \mathrm{H} 4$ ), 3.96 (dd. $1 \mathrm{H} . J=4.8,10.8$ Hz. H5'a), 3.91 (dd, lH, $J=6.8,10.8 \mathrm{~Hz}, \mathrm{H}^{5}$ 'b). 2.92 (s, 3H, $\left.-\mathrm{SO}_{2} \mathrm{CH}_{3}\right), 0.86(\mathrm{~s} .9 \mathrm{H}, t$-butyl), $0.82(\mathrm{~s}, 9 \mathrm{H}, t$-butyl). $0.07(\mathrm{~s}$, $3 \mathrm{H}$. methyl), 0.06 (s. $3 \mathrm{H}$, methyl), $0.00(\mathrm{~s}, 6 \mathrm{H}$, methyl $\times 2$ ); ${ }^{13} \mathrm{C}-\mathrm{NMR} \delta 155.54,153.12,149.67 .138 .33 .119 .46 .89 .71$, $80.68,79.62 .60 .22,38.08,25.80 .25 .46 .18 .26,17.72,-5.08$, $-5.10 .-5.34 .-5.42$.

9-[2'- $O$-(Methanesulfonyl)-3',5'-bis- $O$-(tert-butyldimethy]silyl)-1- $\boldsymbol{\theta}$-D-arabinofuranosyl]adenine (16) Treatment 15 (1.07 g. $2.16 \mathrm{mmol})$ by procedure D [DMAP (0.79 g. 6.48 mmol) in $\mathrm{CH}_{2} \mathrm{Cl}_{2}(20 \mathrm{~mL}) /$ methanesulfonyl chloride $(0.2$ $\mathrm{mL}, 2.59 \mathrm{mmol} / 0.1 \mathrm{~mL} .1 .29 \mathrm{mmol})]$ gave 16 ( $1.15 \mathrm{~g}, 93 \%$ ) as a colorless solid: mp: $62-64{ }^{\circ} \mathrm{C} ;{ }^{1} \mathrm{H}-\mathrm{NMR} . \mathrm{CDCl}_{3} \delta 8.25$ (s, IH. H8), 7.98 (s, IH. H2), 6.45 (d. $1 \mathrm{H}, J=4.4 \mathrm{~Hz}, \mathrm{HL}$ ), 6.14 (br. $2 \mathrm{H} . \mathrm{NH}_{2}$ ). $5.0 \mathrm{l}$ (t. lH. $J=4.4 \mathrm{~Hz} . \mathrm{H} 2$ ), 4.64 (t. IH. $J=4.0 \mathrm{~Hz} . \mathrm{H} 3$ ) $, 3.9 \mathrm{l}(\mathrm{m}, \mathrm{lH} . \mathrm{H} 4), 3.78$ (m. IH. H5'a, H5'b). 2.45 (s. $\left.3 \mathrm{H},-\mathrm{SO}_{2} \mathrm{CH}_{3}\right), 0.82(\mathrm{~s}, 18 \mathrm{H}, t$-butyl $\times 2), 0.08$ (s, 3H. methyl), 0.06 (s, 3H. methyl), 0.01 (s, 3H. methyl), 0.00 (s. $3 \mathrm{H}$. methyl): ${ }^{13} \mathrm{C}-\mathrm{NMR} \delta$ $155.60,153.21$. 149.41, 
139.63. 119.10. 84.81. 82.63, 82.45. 74.94. 61.77, 37.85 . $25.89,25.60,18.38,17.81,-4.62 .-4.97,-5.39,-5.42$.

3'-Azido-3'-deoxy-2',5'-bis-O-(tert-butyldimethylsilyl)adenosine (18). Procedure E. $\mathrm{NaN}_{3}(0.11 \mathrm{~g} .1 .71 \mathrm{mmol})$ was added to a solution of $14(0.22 \mathrm{~g} .0 .34 \mathrm{mmol})$ in anthydrous DMF $(4 \mathrm{~mL})$ and the reaction was stirred at ambient temperature for $3 \mathrm{~h}$ under Ar atmosphere. The reaction was diluted with $\mathrm{H}_{2} \mathrm{O}(20 \mathrm{~mL})$ and then extracted with EtOAc $(20 \mathrm{~mL} \times 2)$. The combined organic phase was washed with brine, dried over $\mathrm{MgSO}_{4}$. filtered. and evaporated to give $18(0.19 \mathrm{~g}, 99 \%)$ as a colorless powder: mp: 106-109 ${ }^{\circ} \mathrm{C}$ : IR (KBr) cm${ }^{-1} 2107$ (strong. $-\mathrm{N}_{3}$ ); ${ }^{1} \mathrm{H}$ NMR, $\mathrm{CDCl}_{3} \delta 8.17$ (s. $\mathrm{HH}, \mathrm{H} 8$ ). $8.0 \mathrm{l}$ (s. $\mathrm{lH}, \mathrm{H} 2$ ), 5.96 (br. $2 \mathrm{H}, \mathrm{NH} 2), 5.88$ (d. 1 H. $J=4.0 \mathrm{~Hz} . \mathrm{HI}$ ), 4.71 (t. 1 H. $J=4.0$ Hz, H2'), 4.07 (m. IH. H3'), 3.92 (m, lH, H4'). 3.91 (m. lH. H5'a). 3.68 (dd, IH. $J=2.0 .11 .6 \mathrm{~Hz} . \mathrm{H}^{5} \mathrm{~b}$ ), 0.79 (s, 9H. $t$-butyl). 0.71 (s, $9 \mathrm{H}, t$-butyl). 0.00 (s. $3 \mathrm{H}$. methyl), $-0.0 \mathrm{l}$ (s. $3 \mathrm{H}$, methyl), -0.08 (s. 3H. methyl). -0.19 (s, 3H, methyl): ${ }^{13} \mathrm{C}-\mathrm{NMR} \delta$ 155.53. 153.01, 149.61, 138.84, 119.92, 88.88. $81.99,76.96,62.39 .60 .88 .25 .94,25.55,18.43 .17 .90,-5.08$. $-5.14 .-5.36,-5.51 ; \mathrm{MS}$ (FAB) $[\mathrm{M}+\mathrm{H}]^{+} 521$.

2'-Azido-2'-deoxy-3',5'-bis-O-(tert-butyldimethylsilyl)adenosine (20). Treatment of $17(0.80 \mathrm{~g}, 1.27 \mathrm{mmol})$ by procedure $\mathbf{E}\left[\mathrm{NaN}_{3}(0.42 \mathrm{~g} .6 .37 \mathrm{mmol}) / \mathrm{DMF}(15 \mathrm{~mL})\right]$ gave $20(0.66$ g. $99 \%)$ as a colorless powder. mip: $132.135^{\circ} \mathrm{C}:{ }^{1} \mathrm{H}$ NMR, $\mathrm{CDCl}_{3} \delta 8.27$ (s. $1 \mathrm{H}, \mathrm{H} 8$ ). $8.0 \mathrm{l}$ (s. $1 \mathrm{H}, \mathrm{H} 2$ ), 6.06 (br. $\left.2 \mathrm{H}, \mathrm{NH}_{2}\right), 6.05\left(\mathrm{~d}, 1 \mathrm{H}, J=5.2 \mathrm{~Hz} . \mathrm{Hl}^{\prime}\right), 4.63$ (t. $\mathrm{lH} . J=5.2$ $\left.\mathrm{Hz}, \mathrm{H} 2^{\prime}\right), 4.41$ (t. $\left.1 \mathrm{H}, J=4.8 \mathrm{~Hz} . \mathrm{H}^{\prime}\right), 4.04\left(\mathrm{~m} .1 \mathrm{H} . \mathrm{H} 4^{\prime}\right)$. 3.88 (dd, $1 \mathrm{H} . J=3.6 .11 .2 \mathrm{~Hz}, \mathrm{H}^{\prime}$ 'a). 3.68 (d. $1 \mathrm{H} . J=11.2$ $\mathrm{Hz}, \mathrm{H} 5^{\prime}$ b), 0.88 (s, 9H, $t$-butyl). 0.81 (s. $9 \mathrm{H}$. $t$-butyl) 0.10 (s. $3 \mathrm{H}$, methyl). 0.08 (s. $3 \mathrm{H}$, methyl). 0.00 (s. $3 \mathrm{H}$, methyl). -0.01 (s, 3H, methyl): ${ }^{13} \mathrm{C}-\mathrm{NMR} \delta 155.70 .153 .13,149.58$. 139.08. 120.00. 86.03. 85.50, 72.30. 65.12. 61.86, 25.89 . $25.85,18.35,18.03 .-4.72 .-4.98,-5.36 .-5.47$; MS (FAB) $[\mathrm{M}+\mathrm{H}]^{+} 521$.

Azidation of compound 13. Procedure F. To the mixture of $\mathrm{NaN}_{3}(0.13 \mathrm{~g} .1 .93 \mathrm{mmol})$ and $\mathrm{Li}_{2} \mathrm{CO}_{3}(0.142 \mathrm{~g} .1 .93$ mmol) in anhydrous DMF $(4 \mathrm{~mL})$ pre-heated at $120^{\circ} \mathrm{C}$ for 3 hours was added $13(0.22 \mathrm{~g} .0 .39 \mathrm{mmol})$ and stirred at 120 ${ }^{\circ} \mathrm{C}$ and was stirred for 3 days. The reaction was diluted with $\mathrm{H}_{3} \mathrm{O}(50 \mathrm{~mL})$ and then extracted with EtOAc $(50 \mathrm{~mL} \times 3)$. The combined organic phase was washed with brine. dried over $\mathrm{MgSO}_{4}$. filtered, and evaporated. The residue was applied to flash column chromatography to give $18(0.08 \mathrm{~g}$. $43 \%)$ and $19(0.01 \mathrm{~g} .6 \%)$ as a white powder: 19: $\mathrm{mp}: 190$ $192{ }^{\circ} \mathrm{C}:{ }^{\mathrm{H}} \mathrm{H}-\mathrm{NMR} . \mathrm{CDCl}_{3} \delta 8.43$ (s. $\mathrm{lH}, \mathrm{H} 8$ ). 7.91 (s, $1 \mathrm{H}$. H2), 7.36 (d. $1 \mathrm{H} . J=12.0 \mathrm{~Hz}$. $-\mathrm{OH}$. exch), 6.07 (br. $2 \mathrm{H}$. $\mathrm{NH}_{2}$ ). 5.84 (d. $1 \mathrm{H}, J=7.2 \mathrm{~Hz} . \mathrm{Hl}$ '), 5.46 (dd, $1 \mathrm{H}, J=7.2$. $\left.8.0 \mathrm{~Hz} . \mathrm{H} 2^{\prime}\right), 4.36$ (d. $\left.1 \mathrm{H}, J=6.0 \mathrm{~Hz}, \mathrm{H} 3^{\prime}\right) .4 .24(\mathrm{~m}, \mathrm{lH}$. H4'). 4.04 (d, $\left.1 \mathrm{H}, J=12.4 \mathrm{~Hz}, \mathrm{H} 5^{\prime} \mathrm{a}\right) .3 .79\left(\mathrm{~m}, \mathrm{lH}, \mathrm{H} 5^{\prime} \mathrm{b}\right)$. 0.88 (s. $9 \mathrm{H}, t$-butyl). 0.00 (s. $3 \mathrm{H}$, methyl). -0.35 (s, 3H. methyl): ${ }^{13} \mathrm{C}$-NMR $\delta$ 156.03. $152.56,148.48$. 140.81 . 121.22. 90.74, 85.48. 74.61. $63.95,63.46,25.4817 .76$, $18.03,-5.16 .-5.98$.

Azidation of Compound 16. Treatment of 16 by procedure $\mathbf{F}(0.37$ g. $0.65 \mathrm{mmol})\left[\mathrm{NaN}_{\hat{3}}(0.21\right.$ g. 3.24 $\mathrm{mmol}) / \mathrm{Li}_{2} \mathrm{CO}_{3}(0.24 \mathrm{~g} .3 .24$ munol) for 4 days] gave $20(0.05$ g. $15 \%)$ and $21(0.05$ g. $15 \%)$ as a white powder: $21: \mathrm{mp}$ : 193.195 ${ }^{\circ} \mathrm{C}:{ }^{1} \mathrm{H}-\mathrm{NMR}, \mathrm{CDCl}_{3} \delta 8.10$ (s. lH. H8), 8.02 (s, lH. H2). 6.89 (br. $2 \mathrm{H} . \mathrm{NH}_{2}$ ), 6.13 (d, $\mathrm{lH}, J=4.4 \mathrm{~Hz} .-\mathrm{OH}$, exch), 5.89 (d. $1 \mathrm{H} . J=3.2 \mathrm{~Hz}, \mathrm{HI}$ ). 4.52 (m. $\left.1 \mathrm{H} . \mathrm{H} 2^{\prime}\right), 4.30$ $\left(\mathrm{dd}, \mathrm{H} . J=4.8 .10 .4 \mathrm{~Hz} . \mathrm{H} 3^{\prime}\right) .4 .15\left(\mathrm{~m} . \mathrm{lH}, \mathrm{H} 4^{\prime}\right) .3 .80(\mathrm{~m}$, 2H. H5'a, H5'b). 0.80 (s, 9H, t-butyl). 0.00 (s, $6 \mathrm{H}$. methyl $\times$ 2); ${ }^{13} \mathrm{C}$-NMR $\delta 155.67,155.61,152.47,149.13,118.75$, $88.19,78.29 .66 .28 .61 .29 .25 .45 .17 .79 .-5.78 .-5.92$.

3'-Amino-3'-deoxy-2',5'-bis- $O$-(tert-butyldimethylsilyl)adenosine (22). Procedure G. A solution of $18(0.10 \mathrm{~g}, 0.19$ mumol) in $\mathrm{MeOH}(10 \mathrm{~mL})$ was hydrogenated at ambient pressure and temperature in the presence of $10 \% \mathrm{Pd} / \mathrm{C}(20$ $\mathrm{mg}$ ) for 16 hours. The mixture was filtered with the aid of celite, and the filtrate was evaporated. The residue was applied to flash column chromatography to give $22(0.09 \mathrm{~g}$. $92 \%$ ) as a colorless powder: mp: $167-169^{\circ} \mathrm{C}$; ${ }^{1} \mathrm{H}-\mathrm{NMR}$. $\mathrm{CDCl}_{3} \delta 8.22(\mathrm{~s}, \mathrm{lH}, \mathrm{H} 8), 8.20(\mathrm{~s}, \mathrm{lH}, \mathrm{H} 2), 5.91(\mathrm{~s}, \mathrm{lH}$, HI') 5.79 (br. $2 \mathrm{H} . \mathrm{NH}_{2}$ ), 4.25 (t. lH, $J=3.6 \mathrm{~Hz} . \mathrm{H} 2^{\prime}$ ). 3.98 (d. $1 \mathrm{H}, J=9.6 \mathrm{~Hz}, \mathrm{H} 5$ 'a). $3.80\left(\mathrm{~m}, \mathrm{lH} . \mathrm{H} 4^{\prime}\right) .3 .79(\mathrm{~m}, \mathrm{lH}$. H5'b). 3.49 (dd, $\left.J=4.4 .8 .0 \mathrm{~Hz}, \mathrm{H} 4^{\prime}\right), 0.83$ (s. 9H. $t$-butyl), 0.82 (s. $9 \mathrm{H}$, t-butyl) 0.09 (s, 3H. methyl), 0.03 (s. $3 \mathrm{H}$, methyl). 0.02 (s. $3 \mathrm{H}$. methyl). 0.00 (s. $3 \mathrm{H}$. metlyl); ${ }^{13} \mathrm{C}$ NMR $\delta$ 155.30. 152.76, 149.35, 139.07, 119.95. 89.74, $84.93,77.82 .61 .91,52.19,26.02 .25 .77 .18 .56,18.03,-4.50$. -5.04. -5.30. -5.44: MS (FAB) $[\mathrm{M}+\mathrm{H}]^{+} 495$.

2'-Amino-2'-deoxy-3',5'-bis-O-(tert-butyldimethylsilyl)adenosine (24). Hydrogenation of $\mathbf{2 0}(0.5 \mathrm{~g} .0 .96 \mathrm{mmol})$ by procedure $\mathbf{G}$ gave $\mathbf{2 4}(0.43 \mathrm{~g} .90 \%)$ as a colorless powder mp: $145.147^{\circ} \mathrm{C}$ : ${ }^{1} \mathrm{H}-\mathrm{NMR}, \mathrm{DMSO}-\mathrm{d} 6 \delta 8.15$ (s, 1H. H8). 7.97 (s, 1H. H2), 7.13 (br, 2H. NH $)_{2} .5 .53$ (d, lH. $J=7.6 \mathrm{~Hz}$. $\left.\mathrm{HI}^{\prime}\right), 4.08$ (d. IH. $J=4.8 \mathrm{~Hz}, \mathrm{H}^{\prime}$ ). $4.0 \mathrm{l}$ (dd. IH. $J=4.8,7.6$. H2'), 3.79 (m, IH. H4'). 3.73 (dd, IH. $J=4.4 .11 .2$. H5'a). $3.52\left(\mathrm{dd}, J=4.0 .11 .2 \mathrm{~Hz} . \mathrm{H} 5^{\prime}\right.$ b) 1.59 (br, $1.5 \mathrm{H}, \mathrm{H}^{\prime}-\mathrm{NH}_{2}$, exch), 0.78 (s. 9 H. $t$-butyl), 0.73 (s, 9H. t-butyl). $0.00(\mathrm{~s}, 6 \mathrm{H}$, methyl $\times 2), 0.09(\mathrm{~s}, 6 \mathrm{H}$, methyl $\times 2),{ }^{13} \mathrm{C}-\mathrm{NMR} \delta 156.05$, $152.48,149.72,139.80,119.22 .87 .94,85.64,73.80 .62 .86$, $56.20,25.78,25.76 .18 .00$. 17.89. $-4.72,-4.78 .-5.49,-5.51$; $\mathrm{MS}$ (FAB) $[\mathrm{M}+\mathrm{H}]^{-} 495$.

3'-Amino-3'-dleoxyadenosine (23). Procedure H. A solution of $22(0.1 \mathrm{~g} .0 .20 \mathrm{mmol})$ and $\mathrm{NH}_{4} \mathrm{~F}(0.09 \mathrm{~g} .1 .76$ mumol) in $\mathrm{MeOH}(10 \mathrm{~mL})$ was stirred in oil bath at $60^{\circ} \mathrm{C}$ for 12 hours. The solvent was evaporated and the resulting solid was partitioned between $\mathrm{H}_{2} \mathrm{O} / \mathrm{EtOAc}$. The aqueous phase was concentrated to $3 \mathrm{~mL}$ and applied to ion-exchange resin colunn cluromatography (Dowex $1 \times 20-200$. OH- form. $2 \times 18 \mathrm{~cm}$ ). The column was washed with $\mathrm{H}_{2} \mathrm{O}$ and eluted with $20-50 \% \mathrm{MeOH}$. The chromatographically identical fractions $\left(\mathrm{BuOH}-\mathrm{AcOH}-\mathrm{H}_{2} \mathrm{O}=60: 15: 25\right)$ were collected, and the solvent evaporated to give $23(0.05 \mathrm{gg} .85 \%)$ with reported properties. ${ }^{\text {? }}$

2'-Amino-2'-deoxyadenosine (25). Treatment of $24(0.39$ g. $0.78 \mathrm{mmol})$ by procedure $\mathbf{H}\left[\mathrm{NH}_{4} \mathrm{~F}(0.29 \mathrm{~g} .7 .88 \mathrm{mmol})\right.$ in $\mathrm{MeOH}(15 \mathrm{~mL})]$ gave $25(0.18 \mathrm{~g} .87 \%)$ as a colorless powder with reported properties. ${ }^{8}$

3'-Azido-3'-deoxyadenosine (26). Treatment of $\mathbf{1 8}(0.50$ g. $0.90 \mathrm{mmol})$ by procedure $\mathrm{H}\left[\mathrm{NH}_{4} \mathrm{~F}(0.50 \mathrm{~g} .12 .63 \mathrm{mmol})\right.$ in $\mathrm{MeOH}(15 \mathrm{~mL})]$ gave $26(0.28 \mathrm{~g} .99 \%)$ as a colorless 
powder with reported properties.

2'-Azido-2'-deoxyadenosine (27). Treatment of $20(0.60$ g. $1.15 \mathrm{mumol})$ by procedure $\mathrm{H}\left[\mathrm{NH}_{4} \mathrm{~F}(0.60 \mathrm{~g} .16 .13 \mathrm{mumol})\right.$ in $\mathrm{MeOH}(15 \mathrm{~mL})]$ gave $27(0.34 \mathrm{~g}, 99 \%)$ as a colorless powder with reported properties."

Acknowledgements. This work was supported by grant No. R01-2002-000-00114-0 from the Basic Research Progran of the Korea Science \& Engineering Foundation.

\section{References}

1. For the excellent reviews. see (a) Guse. A. H. J. Mol hed. 2000. 78. 26. (b) Zhang. F.-J.: Gu. Q.-M.: Sil. C. J. Bioorg \& Med. Chem 1999. 7. 653 . (c) Lee. H. C.: Munshi, C: Graeff R. Mol. Cell. Biochent 1999. 193. 89. (d) Takasawa, S: Nata. S: Yonekura. H.: Okamoto. H. Science $1993,259.370$. (d) Lee, H. C. Hol \& Cell Biochem. 1994. 138. 229. (e) Currie. K.: Swann. K: Galione. A.: Scott. R. H. Mol. Biol. Cell 1992. 3. 1415

2. (a) Takasawa. S.: Akiyama. T.: Nata. K.: Kuroki. M.: Tohgo. A.: Noguchi, N.: Kobavashi. S.: Kato. I.: Katada. T.: Okamoto. H. $J$. Biol. Chem 1998, 273, 2497. (b) Takasawa. S: Nata. K: Yonekura. H.: Okamoto H. Science 1993. 259.370.

3. (a) Jayaraman. T: Ondriasova. E.: Ondrias. K.: Harnick. D. J: Marks. A. R. Proc. Nafl .Acad Sci. 1995. 92. 6007. (b) Guse. A. H.: da Silva. C. P.: Berg. I.: Weber. K.: Heyer. P: Hohenegger. M.: Ashamu, G. A.; Skapento. A. L.: Schulze-Koops, H.: Potter, B. V. L.: Mavr G. W. Nature 1999, 398.70.

4. Rakovic. R. Cui, Y, Ino. S.; Galione A.: Ashamu, G. A.: Potter
B. V. L.: Terrar. D. A. J. Biol. Chem. 1999. 274. 17820.

5. (a) Bailey. V. C.: Sethi. I. K.: Fortt. S. M.: Galione. A.: Potter. B. V. L. Chentisty \& Biology 1997. f, 51. (b) Shuto. S.: Fukuoka M:; Manikowskr, A.; Ueno. Y; Nakano, T.: Kuroda. H.: Kuroda H. Matsuda, A. J. Am. Chent Soc. 2001, 123.8750. (c) Wong, L.; Aarhus. R.: Lee. H. C.: Walseth. T. F. Biochm. Biophlys Acto 1999. 1472.555 .

6. Chent. B.-C.: Quindan. S. L.: Reid. I. G. Tetrahedron Lett. 1995. 36.7961 .

7. Samano, M. C.: Robins, M. J. Tetrahedron Lett. 1989. 30, 2329.

8. Van Calenbergh. S: Van Den Eeckhout, E.; Herdewijn, P.: De Bruyın. A.: Verlinde. C. L. M. J.: Hol. W. G. T.: Callens. M.: Van Aerschot. A.: Rozenski. J. Hetv Chim. Acta 1994. 77.631

9. Botta. O.: Moyroud. E.: Lobato. C.: Strazewski. P. Tetrahedron 1998. $5+13529$.

10. Ogilvie. K. K.; Beaucage, S. L: Schifman, A. L:; Theriault, N. Y: Sadana. K. L. Can. J. Chent 1978, 56,2768.

11. (a) Robins. M. T.: Sarker. S.: Saman1o. V:: Wnuk. S. F. Tetrahedron 1997. 53. 447. (b) Hansshe. F: Madej. D: Robins. M. J. Tetrahedron 1984. 40.125.

12. (a) Kawashima, E.: Aovama, Y.: Radwan, M. F.: Myahara. M: Sekine. T.: Kainosho. M: Kyogoku. Y.; Ishido, Y. Nucleosides Nucleotides 1995, 14. 333. (b) Robins, M. J.; Samano, V: John1sont. M. D. J. Org. Chem. 1990. 55.410. (c) Wu. T.C.: Bazin. H.: Chattopadhyaya. J. Tetrahedron 1987. 43.2355

13. Czernecki. S.: Valéry. J.-M. Sunthesis 1991. 239

14. Bressi. J. C.: Verlinde, C. L. M. J.: Aronov, A. M.; Le Shaw, M.; Shin. S. S. Nguyen. L. N.; Suresh, S.: Buckner. F. S.; Van Voorhis. W. C.; Kuntz, I. D:; Hol. W. G. J.: Gelb. M. H. J. Med. Chem. 2001. H. 2080 .

15. Zhang. W.: Robins. M. J. Tetrahedron Lett. 1992. 33.1177. 